\title{
SOUTH AFRICAN ELITES AND CHRISTIAN ETHICS (II) \\ - SOCIAL ETHICS
}

\author{
J Kinghorn, HJ Kotze
}

University of Stellenbosch

\begin{abstract}
South Africa is generally seen as a country in which religious values play a significant role, particularly Christian values. Such statements are, however, extremely difficult to qualify adequately. In this article the results from a national survey among elites conducted in both 1994 and 1995 are employed to gain some insight into the role the Christian faith plays with regard to ethical issues in the process of policy-making in South Africa. The article is a presentation of data which may contribute to a better understanding of the influence of Christian norms and beliefs in the area of social.
\end{abstract}

\section{Introduction}

This article also draws on the Longitudinal Study of the South African Elite and their Attitudes regarding Political Change ${ }^{I}$ done at Stellenbosch under the supervision of the department of Political Science, which for the first time provides researchers with empirical data substantial enough to attempt a more sophisticated understanding of the religious factor in our public life.

Like the previous article data collected during 1994 and 1995 are utilised. In this article the focus is on the nexus between religion, values and societal ethics. ${ }^{2}$. As Southern African academic and socio-ethical discourse has been dominated for decades by ideological posturing and propaganda a thorough analysis of the prevailing interface between values and socio-ethics is in short supply. Undoubtedly religion is one of and perhaps the main source in this respect. The relevance of surveys which yield significant results with regard to the interface of religion and societal ethics is, therefore, evident.

Useful though it may be, the data drawn upon does not allow incontestable conclusions. For one thing, the data stem from a rather select target group. It does not necessarily follow that church publics in South Africa hold these views generally. Further surveys are required to test this.

1 This is a positional elites study. HJ Kotzé argues that “...elites are the societal agents through which broader forces such as etnicity, class, religion, etc. are filtered to ordinary people; elites give predictable thrust to the functioning of political regimes; ....elites... are indeed the 'switchmen of history'.... The operational definition of elites for the purposes of the survey is "those persons who hold authoritative positions in powerful public and private organisations and influential movements, and who are therefore able to affect strategic decisions regularly". (Research Report No 3 of 1992, p 17. Centre for International and Comparative Politics: Stellenbosch) 2 The groups were categorised as follows: Afrikaans Mainline consists of the Dutch Reformed Church, Dutch Reformed Mission Church, Reformed Church, Afrikaanse Protestantse Kerk and the Hervormde Kerk. The English Mainline churches comprise: the Anglican Church (including variants), Methodist Church,

Congregational Church, Lutheran Church, Baptist Church, Roman Catholic. The non-religious category consists of those who either expressed opposition to religion, a preference for atheism or merely indifference. Finally the non-mainline group are those who do not fall into any one of the above categories. This group includes, for example, various Pentecostal movements and indigenous churches. In the sample there is a bias toward the Afrikaans mainline churches. Nevertheless, the overall sample is big enough to allow a grouping of the data into four distinct categories, yielding useful comparative material.

The overall ratio of the four groups did not vary from 1994 to 1995 . As neither ethical norms in general nor ethical principles held by individuals change easily it is, therefore, acceptable to use the data from the two surveys interchangeably. 
This article does not pretend to provide an overall picture of Christian socio-ethical positions in South Africa. This article merely wants to make available the findings - relative and sectored as they are - of the surveys referred to above. It is no more than a contribution to a much more complex and as yet unfinished picture.

The graphs are more or less self-explanatory. A few overall comments should be made though.

\section{Overall comments}

The survey questions covered a wide variety of topics. From these only the following areas produced noticeable results (from the point of view of Christian ethics, that is): the public place and format of religion, racial categorisation, national ideals, the degree of state intervention in public life, market orientation and, finally, work ethic. A short note on each of these will now be made.

\section{The public place of religion}

It is quite clear that an almost universal agreement exists that the state should not treat any one religion preferentially. Of those who disagree the majority is from the Afrikaans mainline churches. But the number is insignificantly small.

When the same issue surfaces as the question whether religious instruction should be given in schools, the "American way" is, however, rejected. A sizeable majority do want religious instruction as part of the school curricula. In fact this is the majority position in the non-religious group too.

It would thus be fair to describe the general position as a benevolent or positive liberalism vis-à-vis religions as factors in the societal web. No preferential treatment, but also but also exclusion.

\section{Racial categorisation}

Christian Nationalism used to function as a religious expression of racist ideologies in the Afrikaner community. For that reason the Afrikaner churches until recently were almost systemically associated with racism. The questions on mixed schools and the cultural education of children tested degrees of racial exclusivism. The results show that the gap between the Afrikaner church group and the rest is still considerable but by no means as big as sometimes assumed. Taken together the graphs may indicate a shift from a racial to a cultural anthropology within Afrikaner church circles.

\section{National ideals}

There is near unanimity as to the paramount need for the country to accept economic growth as its primary goal (as was subsequently illustrated in the government's shift from the Reconstruction and Development Programme to Growth, Equity and Redistribution Programme).

The reverse, however, of the question about national goals presents us with somewhat unexpected results. The overall rejection of the military is quite clear. Although Afrikaner rejection is less severe than the other groups, it still is demonstrably higher than in all the other options except one. That exception is the response to the question whether the ideal society is one in which the higher dimensions of human life (i.e. ideas) should dominate as opposed to a society constituted by the scramble for existence (i.e. money). Unexpectedly the Afrikaner response is overwhelmingly in favour of the latter. Whereas $20 \%$ of Afrikaner respondents find a strong defence force the least desirable goal, fully $25 \%$ opt for money 
rather than ideas. This is decidedly more than the non-mainline churches whose members, generally speaking, should have much more reason to improve their material conditions than elite Afrikaners.

It would seem that these findings support observations of a strong swing to a materialist and functionalist life orientation in the Afrikaner community.

\section{State intervention}

The previous remark is further supported the results of the two questions related to the degree of state intervention desired. Again there is a general agreement between all groups in favour of a liberal state, but again the intensity of the No! vote by Afrikaners outstrips the other groups noticeably.

\section{Market orientation}

How modernised, then, are the elites?

Clearly the essence of the market economy, the stock exchange, is viewed with a great deal of distrust and antipathy. In this respect there is hardly any difference between the various groups, although one would assume that the reasons advanced for the various positions would differ on theoretical grounds.

\section{Work ethic}

One possible reason for the distrust of the stock exchange could be a deep seated concept of work as propounded by traditional Protestant cultural theory, and often refereed to as the "work ethic." The last three graphs depict the results of three questions testing views on work. The first one approaches the issue from an individual point of view. Immediately the parallel between the Afrikaner and non-mainline responses can be observed, reinforcing remarks made in this respect in the previous article.

But when the question is turned into a macro-format with policy implications (work as a right and the actions of labour unions) there is a clear difference between Afrikaner responses and the rest. This difference can certainly not exclusively be ascribed to the Protestant work ethic, but it would be surprising if it would not feature in any motivation respondents would give were they to be polled as to their reasons for their responses. 


\section{SAMPLE ACCORDING TO CHURCH AFFILIATION}

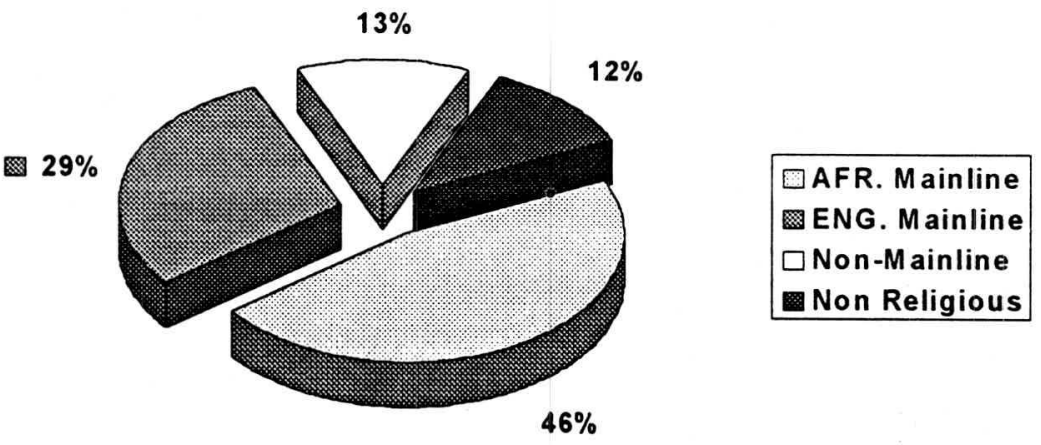

Source: Steilenbosch Elites Survey 1994

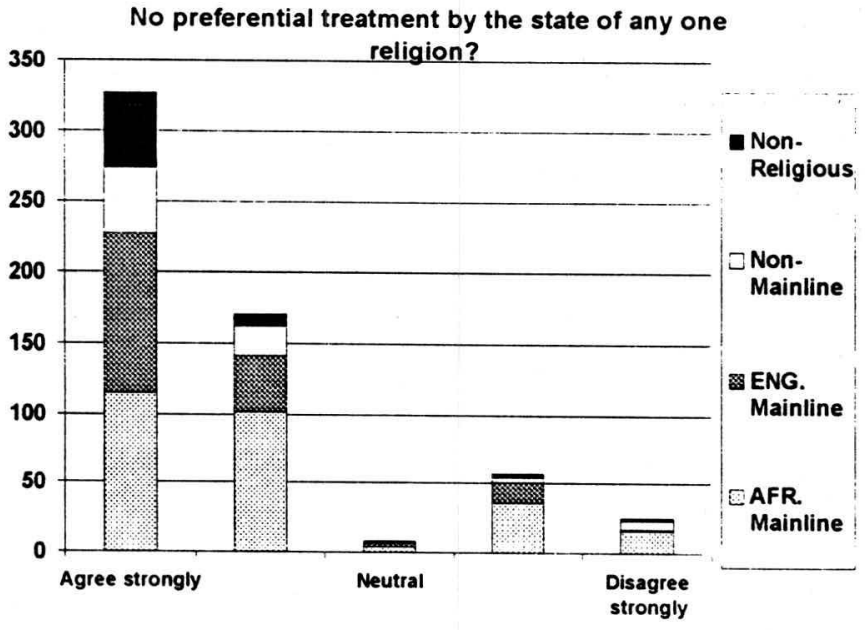

Source: Stellenbosch Elites Survey 1994 
There should be no religious instruction in public schools

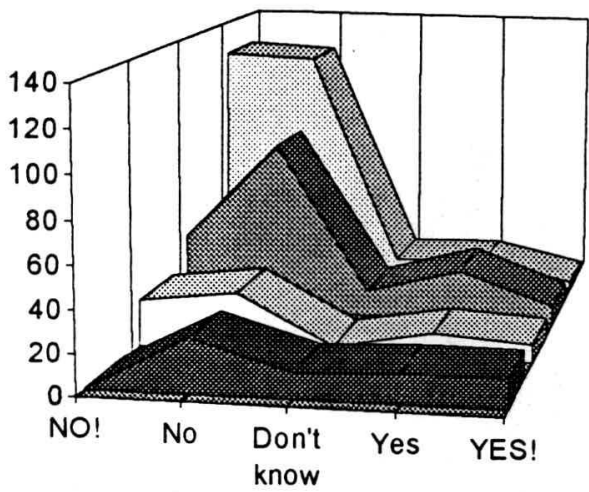

$\rightarrow$ AFR.

Mainline

图 ENG.

Mainline

$\square$ Non-

Mainline

Non-

Religious

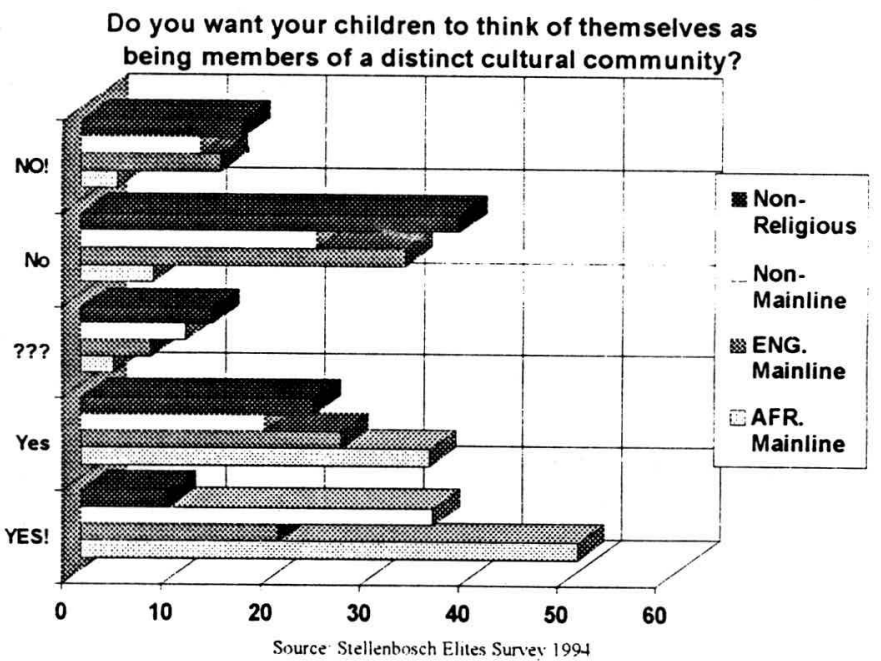




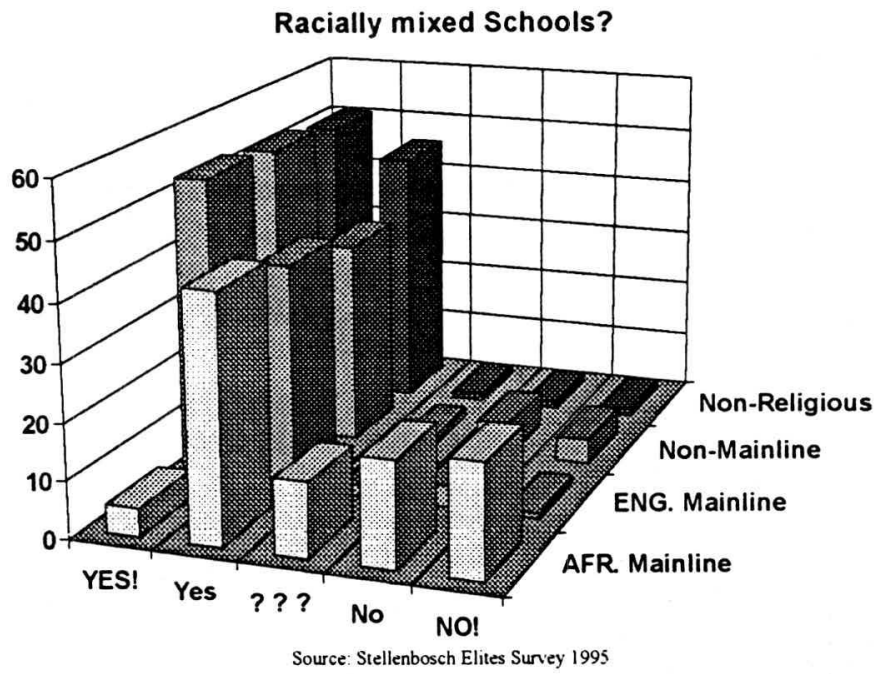

Most desirable goal for our society?

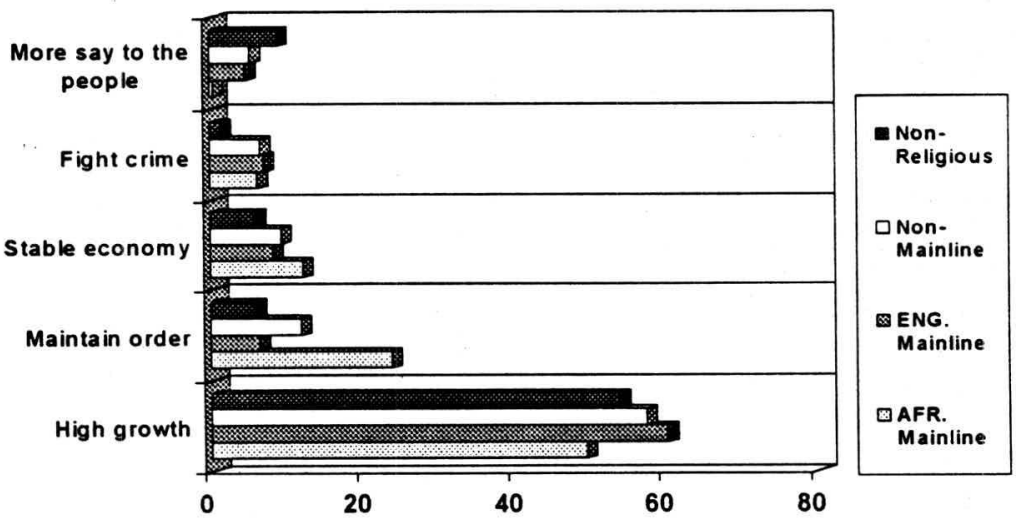

Source: Stellenbosch Elites Survey 1994 


\section{Least desirable goal for our society?}

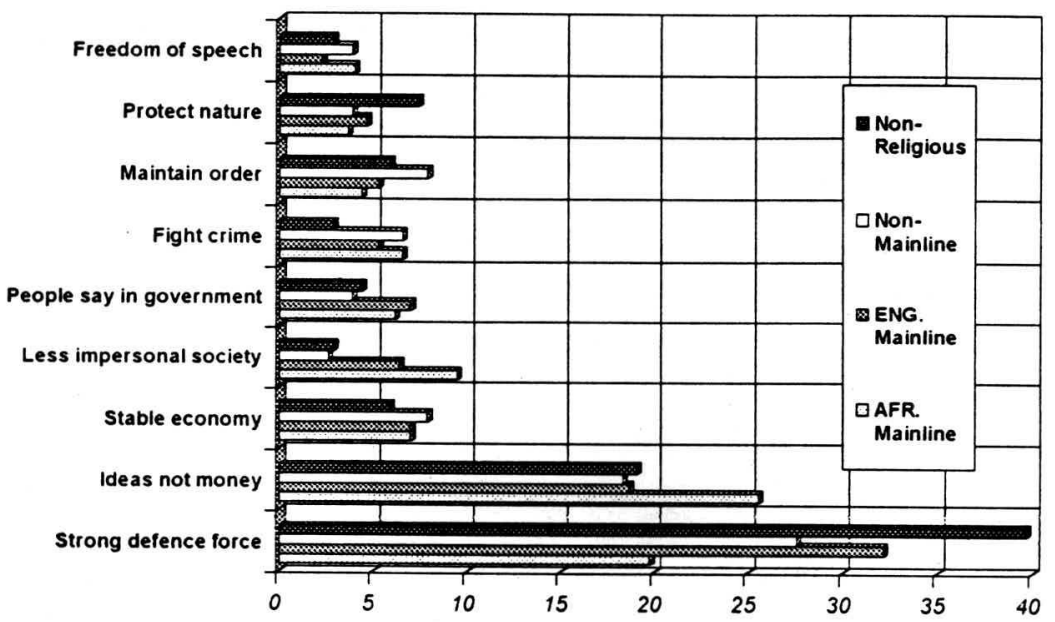

Is it the duty of the state to provide each person with a job and sufficient remuneration?

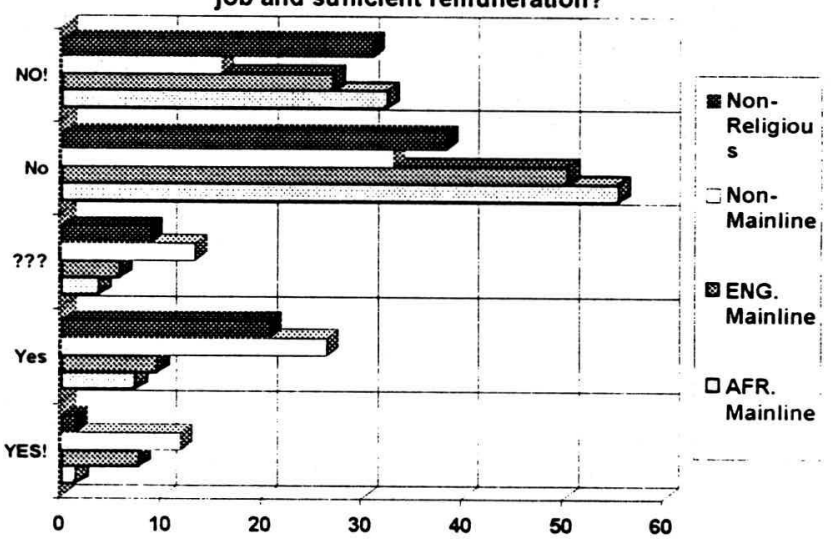

Source Stellenbosch Elites Suncy 1994 
Nationalisation of big companies?

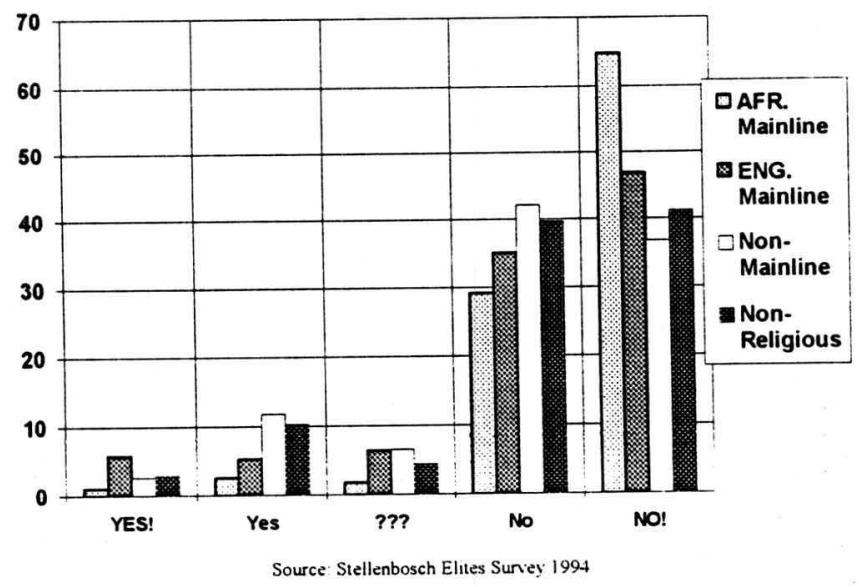

Companies' dealings on the Johannesburg Stock Exchange are suspect?

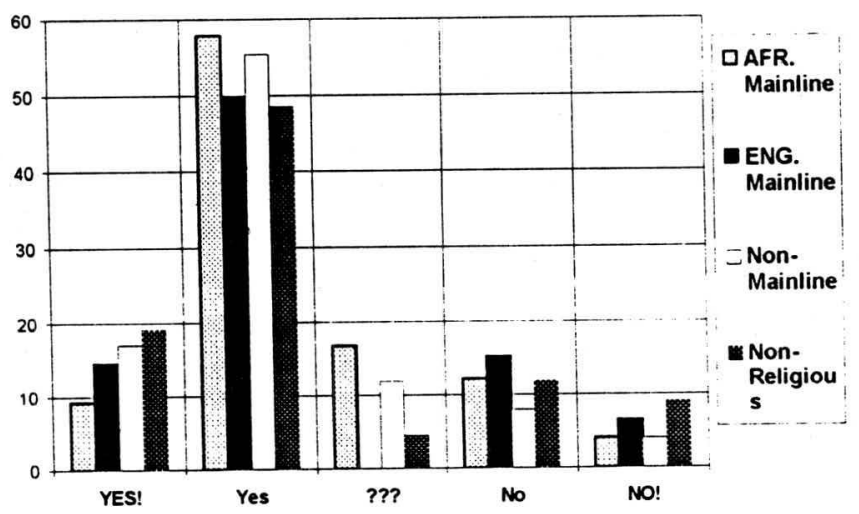

Source: Stellenbosch Elites Survey 1994 
If poor people worked harder they could escape poverty?

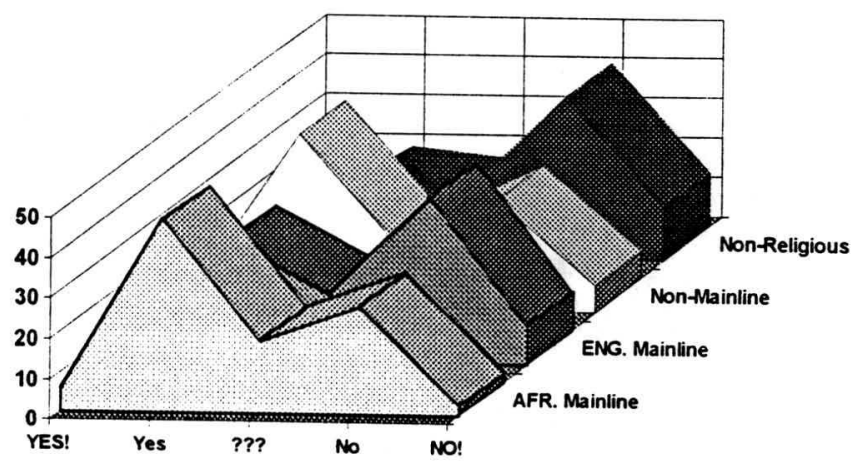

Source Stellenbosch Elites Survey 1994

Work is a right - and the state should provide it

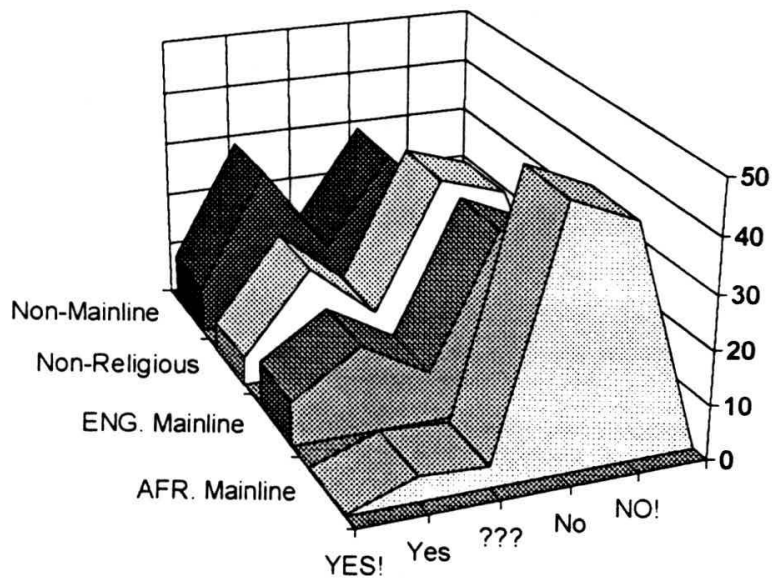

Source Stellenbosch Elites Survey 1995 
The actions of trade unions are usually detrimental to economic growth?

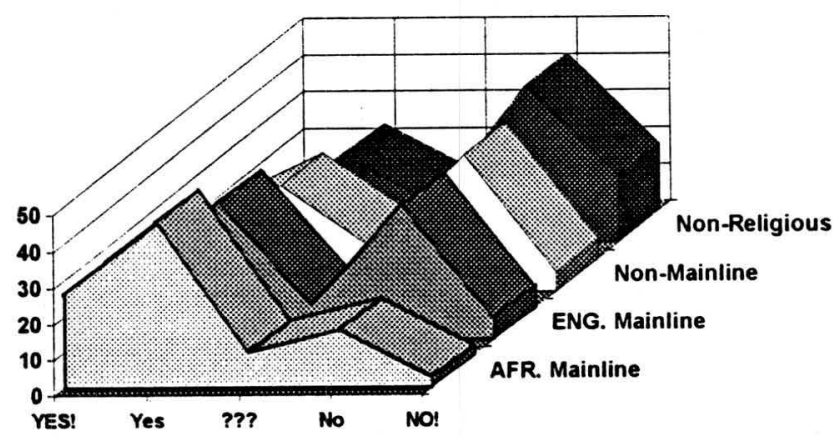

Source: Stellenbosch Elites Survey 1994 